\title{
Investigation of the Mediating Role of Islamic Work Ethic in the Relationship between Spiritual Intelligence and Occupational Self-Efficacy in Red Crescent Relief Workers (Case: Red Crescent Society of Torbat Heydariyeh, Iran)
}

\author{
$\underline{\text { Ahmad Arabshahi Karizi }}{ }^{1}(1)$, Somayeh Asgari ${ }^{2} \mathbb{1}$ \\ Date of submission: 21 Apr. 2020 Date of acceptance: 2 Aug. 2020
}

\section{Original Article}

\begin{abstract}
INTRODUCTION: The present study aimed to investigate the mediating role of Islamic work ethic in the relationship between spiritual intelligence and occupational self-efficacy in the Red Crescent relief workers.

METHODS: This applied research was conducted based on a descriptive-survey design. The statistical population consisted of all Red Crescent relief workers in Torbat Heydariyeh, Iran $(n=146)$. In total, 106 relief workers were selected using simple random sampling and the required data were collected through standard questionnaires. Finally, the collected data were analyzed in SPSS (version?) and Smart PLS software (version?).

FINDINGS: Based on the results, there is a significant positive relationship between spiritual intelligence and occupational self-efficacy of Red Crescent relief workers and the Islamic work ethic is able to mediate this relationship.

CONCLUSION: According to the findings, it can be concluded that it is possible to improve the occupational self-efficiency of relief workers through the development and reinforcement of spiritual intelligence and promotion and institutionalization of Islamic work ethic. Therefore, they will be able to play a more effective role in the achievement of organizational goals.
\end{abstract}

Keywords: Islamic Work Ethic; Occupational Self-efficacy; Spiritual Intelligence.

How to cite this article: Arabshahi Karizi A, Asgari S. Investigation of the Mediating Role of Islamic Work Ethic in the Relationship between Spiritual Intelligence and Occupational SelfEfficacy in Red Crescent Relief Workers (Case: Red Crescent Society of Torbat Heydariyeh, Iran). Sci J Rescue Relief 2020; 12(2): 84-92.

\section{Introduction}

$\mathrm{H}$ uman resource is one of the most important factors in any organization whose effectiveness can be improved through the development of occupational selfefficacy. People with high self-efficacy have high expectations of successful results, persevere in tasks, and often perform on higher levels (1). Moreover, high levels of occupational selfefficacy lead to increased participation in occupational tasks and behaviors (2). People with high self-efficacy choose more challenging goals that require more effort and are more persistent in completing tasks (3). Self-efficacy affects behavior, effort, and perseverance in the pursuit of goals, and determines how one faces obstacles and challenges (4). Self-efficacy of employees can be increased through the reinforcement of various factors in order to make the organization successful.

Spiritual intelligence is one of the components that can affect self-efficacy and has also been emphasized in this research. Spiritual intelligence is a set of adaptive mental capacities based on the immaterial and transcendent aspects of reality (5). Amram (2005) defines spiritual intelligence as the

1-PhD, Department of Public Administration, Payame Noor University, Tehran, Iran

2-MSc, Human Resource Management, Payame Noor University, Tehran, Iran

Correspondence to: Ahmad Arabshahi Karizi, Email: ahmad.arabshahi@gmail.com 
ability to apply and express spiritual values in a way that promotes daily performance as well as physical and mental health.

Santos (2006) considers spiritual intelligence as the ability to know the principles of life as well as natural and spiritual laws and to build life according to them (6). Spiritual intelligence combines the structures of spirituality and intelligence into a new structure (7). It can help a person achieve positive beliefs since it makes human life purposeful which is very helpful in achieving a positive attitude in life (8). The application of spiritual intelligence in life can facilitate the relationship with oneself, others, and God, as well as self-awareness (9).

Another component that has been considered in this study in relation to occupational selfefficacy is the Islamic work ethic. Work ethic is the measured and preferred standards and patterns that govern human behavior that make possible cooperation, peace, and the continuity of collective life (10). Application of ethics and ethical principles in the society are emphasized by Islam, accordingly, the Prophet of Islam has declared that the purpose of his mission was to perfect moral virtues.

Islam is established as a set of practical beliefs and instructions which, according to its Prophet and followers, is sent from God. Morality is defined as a set of teachings that show the proper way of life and the values that govern human behavior. Based on the above-mentioned descriptions, it is possible to understand the close relationship between religion and morality and recognize morality as an inseparable part of religion (11). Work ethic is influenced by the religion of each society and there is a close connection between the two. In Islamic societies, work is valuable in the afterlife as well as in this life (12).

Undoubtedly, a proper moral atmosphere in an Islamic organization requires the establishment of an Islamic work ethic (13). Islamic work ethic expresses a kind of attitude towards work according to which work is piety and also one of the human needs. Moreover, it defines work as a necessity for the achievement of balance in social and private affairs as well as acceptance and consolidation of one's life (14). Work ethic has a prominent place in the Qur'an; for example, in Qur'an, God has repeatedly commanded people to observe the principles of honesty, justice, and fairness in their occupations (15).

Some strategic principles can be used to determine the practical components of Islamic work ethics, such as genuine and unconditional respect for human beings, respect for human freedom, adherence to justice, and trustworthiness in personal behavior and insight (16). The Islamic work ethic model consists of four aspects, including meticulous work, humanitarian work, independence, and social utility (17). Cipity (1995) has also introduced four aspects for Islamic work ethic, namely attachment to and interest in work, perseverance and determination in work, healthy human relationships in the workplace, and collective spirit and participation in work (18).

Islamic work ethic can be defined as a set of moral principles that are based on Islamic concepts and separates moral from immoral (19). Islamic work ethic is in line with the Islamic civilization which emphasizes cooperation and collaboration in work (20). According to the Islamic work ethic, valuable work is defined as a kind of work that is intended to achieve the pleasure of God (21). The present study aimed to investigate the mediating role of Islamic work ethic on the relationship between spiritual intelligence and occupational self-efficacy in the Red Crescent relief workers.

A number of previous studies that have been performed on the subject of this research are briefly reviewed in the following. Karimi (2016) in a study found that there is a significant positive correlation between Islamic work ethic and selfefficacy of professors of basic sciences at Payame Noor University in Shahrekord, Iran (22). According to the findings of another research conducted by Karimi (2014), spiritual intelligence had an association with self-efficacy and occupational stress in teachers. Furthermore, he found that self-efficacy is able to predict spiritual intelligence and there is a relationship between the aspects of spiritual intelligence and self-efficacy (3). Dayyeri et al. (2014) in a study found that self-efficacy, persistence, and coping strategies can be developed and the organization can play an important role in their improvement in the relief workers (23).

Based on the results of a research performed by Mogheri (2014), there is a relationship between spiritual intelligence (general thoughts and beliefs, consideration of moral values and 
self-awareness, and love and interest) and selfefficacy of employees (6). Rajabipour Meybodi et al. (2013) in a study concluded that there is a significant relationship between Islamic work ethic and organizational commitment of nurses, while there is no significant relationship between Islamic work ethic and occupational satisfaction (11). In addition, Mansour Ali et al. (2012), in their study concluded that there is a significant positive relationship between spiritual intelligence and general self-efficacy (24).

Golchin (2012) in a study found that spiritual intelligence has a positive relationship with selfefficacy and that among the dimensions of spiritual intelligence, transcendent awareness had the most significant relationship with selfefficacy. Results of the above-mentioned study also indicated that spiritual intelligence can be developed and its improvement can play an essential role in increasing the self-efficacy of teachers (25).

Santoso in a study (2016) declared that Islamic work ethic had a positive effect on occupation fascination (26). Smith (2010) in another research found that occupational satisfaction has a positive relationship with spirituality and self-efficacy (27). Results of a study performed by Ali and AlKazemi (2007) indicated a significant and strong correlation between Islamic work ethic and loyalty since those who value Islamic work ethics are satisfied with their occupation, and thereby tend to be more committed to it (28).

Based on the findings of a study performed by Rokhman (2010), the Islamic work ethic had positive effects on occupational satisfaction and organizational commitment (29). In another study conducted by Adegbola (2007), a positive relationship was found between spirituality and self-efficacy (30). Ali and Al-Owaihan (2008), in their research, stated that the Islamic work ethic has economic, moral, and social aspects. It seems that these aspects, along with the basic elements of Islamic work ethic, lead to loyalty with a sense of trust and organizational commitment and help the employees stay committed to the organization (13).

According to the results of شresearch conducted by Wigglesworth (2006), people with high spiritual intelligence were able to control critical situations better (31). Besides, McKnight (2005) in a research found that there was a significant relationship between spirituality and life satisfaction. He/she also concluded that the level of life satisfaction was lower in people who had problems with spirituality (32).

\section{Research hypotheses}

- Spiritual intelligence has a relationship with occupational self-efficacy in Red Crescent relief workers.

- Islamic work ethic mediates the relationship between spiritual intelligence and occupational self-efficacy in Red Crescent relief workers.

- Critical existential thinking has a significant positive relationship with occupational selfefficacy in Red Crescent relief workers in Torbat Heydariyeh, Iran.

- Production of personal meaning has a significant positive relationship with occupational self-efficacy in Red Crescent relief workers in Torbat Heydariyeh.

- Transcendental consciousness has a significant positive relationship with occupational self-efficacy in Red Crescent relief workers in Torbat Heydariyeh.

- Expansion of consciousness has a significant positive relationship with occupational selfefficacy in Red Crescent relief workers in Torbat Heydariyeh.

- Healthy human relationships mediate the relationship between spiritual intelligence and occupational self-efficacy in the Red Crescent relief workers.

- Perseverance and determination mediate the relationship between spiritual intelligence and occupational self-efficacy in the Red Crescent relief workers.

- Responsible religious behavior mediates the relationship between spiritual intelligence and occupational self-efficacy of crescent relief workers.

\section{Methods}

This applied research was conducted based on a descriptive correlational design. The statistical population of the study consisted of 146 Red Crescent relief workers in Torbat Heydariyeh and the sample size was determined using the Krejcie and Morgan sample size formula. Finally, 106 relief workers were selected through the simple random sampling method.

The required data were collected through a questionnaire which was made based on three questionnaires, namely the occupational self- 
efficacy questionnaire developed by Riggs and Knight (1994) which includes 31 items, the Islamic work ethic questionnaire developed by Ali Akhlaghi (2015) with 17 items, and spiritual intelligence questionnaire developed by King (2008) with 24 items. Face and content validity of the questionnaire was confirmed by professors and its validity was checked using SmartPLS software (version?).

Confirmatory factor analysis was used to examine the structure of the questionnaire and discover the constituent factors of each structure. Since all the questions have a factor loading of more than 0.3 and have become significant at the confidence levels of $99 \%$ and $95 \%$, it can be said that the items of the questionnaire were able to make a significant contribution to the measurement of the relevant structure. Moreover, the reliability was measured using Cronbach's alpha and the results are summarized in the following table.

Table 1. Cronbach's alpha of research variables Variable Cronbach's alpha

$\begin{array}{ll}\text { Occupational self-efficacy } & 0.88 \\ \text { Islamic work ethic } & 0.80 \\ \text { Spiritual intelligence } & 0.79\end{array}$

Confirmatory factor analysis was used to examine the structure of the questionnaire and discover the constituent factors of each structure. Factor loadings related to research structures were all tested margins of error of 5\% and $1 \%$. Strength of the relationship between the factor (latent variable) and the observable variable is indicated by the factor loading. All the items have a factor loading of more than 0.3 , became significant at the $99 \%$ and $95 \%$ confidence levels, and were able to make a significant contribution to the measurement of the relevant structure. To test the hypotheses of the research, the collected data were analyzed in SPSS (version?) and Smart PLS (version?) statistical software using the descriptive and inferential statistics.

\section{Findings}

In the following, the results of data analysis are presented in the form of descriptive statistics. Moreover, the statistical sample is described based on the data collected by the questionnaire from participants. The data is presented in the form of tables to let the readers access the necessary information quickly and easily.

One type of latent variable relationship in structural equation modeling is based on correlation. Correlation is a non-directional relationship between variables in a model that is evaluated by correlation analysis. Table 3 summarizes the Pearson correlation coefficients for the pairwise examination of the relationships between latent variables. The number 1 is located on the main diagonal of this matrix which means that each variable has a perfect correlation with itself. All correlation coefficients were significant at the confidence level of $99 \%$ (with a p-value of less than 1\%) which indicated that there were pairwise significant relationships among the variables.

Positive and negative coefficients indicate direct (positive) and indirect (negative) relationships between the two variables. Table 3 also shows the validity and reliability of the research questionnaire. The average variance extracted (AVE) for validity is the composite reliability (CR) coefficient for reliability. Fornell and Larker have proposed the use of the AVE criterion for the calculation of the convergent validity. If the AVE value is at least 0.5 , the indices have desirable convergent validity. This means that a latent variable is able to explain more than half of the variance of its indices (observable variables) on average. Given that in this research, the AVE index is higher than 0.5 for all research variables, the convergent validity

Table 2. Frequency distribution of samples in terms of gender, marital status, and age

\begin{tabular}{|ccc|}
\hline Gender & $\begin{array}{c}\text { Absolute } \\
\text { Frequency }\end{array}$ & $\begin{array}{c}\text { Relative Frequency } \\
\text { (percent) }\end{array}$ \\
\hline Male & 94 & 89 \\
Female & 12 & 11 \\
Total & 106 & 100 \\
Marital & Absolute & $\begin{array}{c}\text { Relative Frequency } \\
\text { (percent) }\end{array}$ \\
status & Frequency & 72 \\
Married & 76 & 28 \\
Single & 30 & 100 \\
Total & 106 & Relative Frequency \\
(percent)
\end{tabular}


of the model constructs is confirmed. The $\mathrm{CR}$ evaluates the reliability of a measuring instrument. All these coefficients are higher than 0.7 and indicate the high reliability and validity of the measuring instrument.

In this section, the results of the study and research hypotheses testing are presented based on the analysis using the partial least squares (PLS) method. Path coefficients and t-statistic were used to test the hypotheses. Path coefficients were used to determine the strength of the relationship between the two variables and the tvalue was used to examine the significance of the relationship.

According to the table 4, there was a significant positive relationship between spiritual intelligence and occupational self-efficacy. There was also a significant positive relationship between two components of spiritual intelligence, namely critical existential thinking and the production of personal meaning with occupational self-efficacy. However, there was no significant positive relationship between two of the two components of spiritual intelligence, namely transcendental consciousness and expansion of consciousness, with occupational self-efficacy.

The variance accounted for (VAF) was used to determine the intensity of the indirect effect of the mediating variable. The VAF value varies from 0 to 1 , and the closer it is to 1 , the stronger the effect of the mediating variable is. Based on the results of the VAF test, more than $51 \%$ of the effect of the spiritual intelligence variable on occupational self-efficacy is due to the indirect variable of Islamic work ethic. The results indicate the confirmation of the hypotheses. In the following, the main research models, which are the output of Smart PLS software, are presented in the mode of estimating the coefficients and significance of the coefficients.

In the main model of this research, the variables of spiritual intelligence and Islamic work ethic are independent, while the variable of occupational self-efficacy is dependent. Moreover, the numbers or coefficients are divided into two categories. The first category is called measurement equations, which contains the relationships between latent (elliptical) variables and observable (rectangular) variables. These equations are called factor loading. The second category consists of structural equations which comprises the relationships between latent variables and are used for hypotheses testing. These coefficients are called path coefficients.

The numbers inside the ellipse represent the coefficient of determination. This criterion indicates the effect of the independent variable (exogenous) on the dependent variable (endogenous). The higher values of this criterion indicate the better fit of the model. Three values of $0.19,0.33$, and 0.67 have been introduced as the criterion values for weak, moderate, and strong values. The coefficient of determination of the occupational self-efficacy variable in the main model was equal to 0.449 and showed that the variables of spiritual intelligence and Islamic

Table 3. Evaluation of reliability coefficients, average variance extracted, and correlation coefficients

\begin{tabular}{|lccccc|}
\hline Latent variables & $\mathbf{1}$ & $\mathbf{2}$ & $\mathbf{3}$ & $\mathbf{A V E}$ & $\mathbf{C R}$ \\
\hline Spiritual intelligence & 1.00 & & & 0.7824 & 0.7899 \\
Islamic work ethic & $0.6531^{*}$ & 1.00 & & 0.6981 & 0.8041 \\
Occupational self-efficacy & $0.3255^{*}$ & $0.5957^{*}$ & 1.00 & 0.7332 & 0.8822 \\
\hline
\end{tabular}

$* \mathrm{P}<0.1$

Table 4. Results of research hypotheses testing using the partial least squares method

\begin{tabular}{|c|c|c|c|c|}
\hline Research hypotheses & $\begin{array}{c}\text { Path } \\
\text { coefficient }\end{array}$ & $\begin{array}{c}\text { t- } \\
\text { statistic }\end{array}$ & $\mathbf{P}$ & $\begin{array}{l}\text { Hypotheses } \\
\text { testing result }\end{array}$ \\
\hline Spiritual intelligence $\rightarrow$ Occupational self-efficacy & 0.305 & 2.330 & $<0.05$ & $\begin{array}{l}\text { Confirmation of } \\
\text { the hypothesis }\end{array}$ \\
\hline Critical existential thinking $\rightarrow$ Occupational self-efficacy & 0.773 & 4.801 & $<0.01$ & $\begin{array}{l}\text { Confirmation of } \\
\text { the hypothesis }\end{array}$ \\
\hline Production of personal meaning $\rightarrow$ Occupational self-efficacy & 0.324 & 3.348 & $<0.01$ & $\begin{array}{l}\text { Confirmation of } \\
\text { the hypothesis }\end{array}$ \\
\hline Transcendental consciousness $\rightarrow$ Occupational self-efficacy & 0.213 & 1.651 & $>0.05$ & $\begin{array}{c}\text { Rejection of the } \\
\text { hypothesis }\end{array}$ \\
\hline Expansion of consciousness $\rightarrow$ Occupational self-efficacy & 0.200 & 1.525 & $>0.05$ & $\begin{array}{c}\text { Rejection of the } \\
\text { hypothesis }\end{array}$ \\
\hline
\end{tabular}


work ethic explain $45 \%$ of the variance of the occupational self-efficacy variable. The remaining $55 \%$ is related to the forecasting error and may include other factors that affect occupational selfefficacy.

The type and significance of relationships between variables can be identified according to the software output presented above. The path in the causal model represents the effect of one variable on another. In path analysis, the path is usually represented by a one-way arrow that is drawn from the exogenous variable to the corresponding endogenous variable. If the effect size is negative, it means that the relationship is inverse, while if it is positive, it means that the relationship is direct, and the closer its absolute value is to 0.3 , the stronger the effect is. As can be seen in the figure 1, the value of the path coefficient is positive which indicates that there is a positive relationship between the independent and dependent variables. This means that an increase in the independent variable leads to an increase in the dependent variable. Since the path coefficients are greater than 0.3 , the relationships between variables are strong. The figure 2 shows the main research model in the significant state of coefficients.

The above figure shows the main research model in the mode of coefficient significance. This model tests the measurement equations (factor loadings) and the structural equations (path coefficients) using the t-statistic. The $t$-value is a measure of the relationship of variables in the model; in other words, the t-value is the criterion

Table 5. Results of research hypotheses testing using the partial least squares method (indirect effects)

\begin{tabular}{|c|c|c|c|c|}
\hline Research hypotheses (indirect effects) & $\begin{array}{l}\text { Direct path } \\
\text { coefficient }\end{array}$ & $\begin{array}{l}\text { Indirect path } \\
\text { coefficient }\end{array}$ & $\begin{array}{c}\text { Variance } \\
\text { accounted for }\end{array}$ & $\begin{array}{l}\text { Hypotheses } \\
\text { testing result }\end{array}$ \\
\hline $\begin{array}{l}\text { Spiritual intelligence } \rightarrow \text { Occupational self-efficacy } \\
\text { (with the mediation of Islamic work ethics) }\end{array}$ & 0.305 & 0.327 & 0.517 & Confirmed \\
\hline $\begin{array}{l}\text { Spiritual intelligence } \rightarrow \text { Occupational self-efficacy } \\
\text { (with the mediation of healthy human relationships) }\end{array}$ & 0.291 & 0.358 & 0.552 & Confirmed \\
\hline $\begin{array}{l}\text { Spiritual intelligence } \rightarrow \text { Occupational self-efficacy } \\
\text { (with the mediation of perseverance and } \\
\text { determination) }\end{array}$ & 0.291 & 0.517 & 0.640 & Confirmed \\
\hline $\begin{array}{l}\text { Spiritual intelligence } \rightarrow \text { Occupational self-efficacy } \\
\text { (with the mediation of responsible religious behavior) }\end{array}$ & 0.291 & 0.419 & 0.590 & Confirmed \\
\hline
\end{tabular}

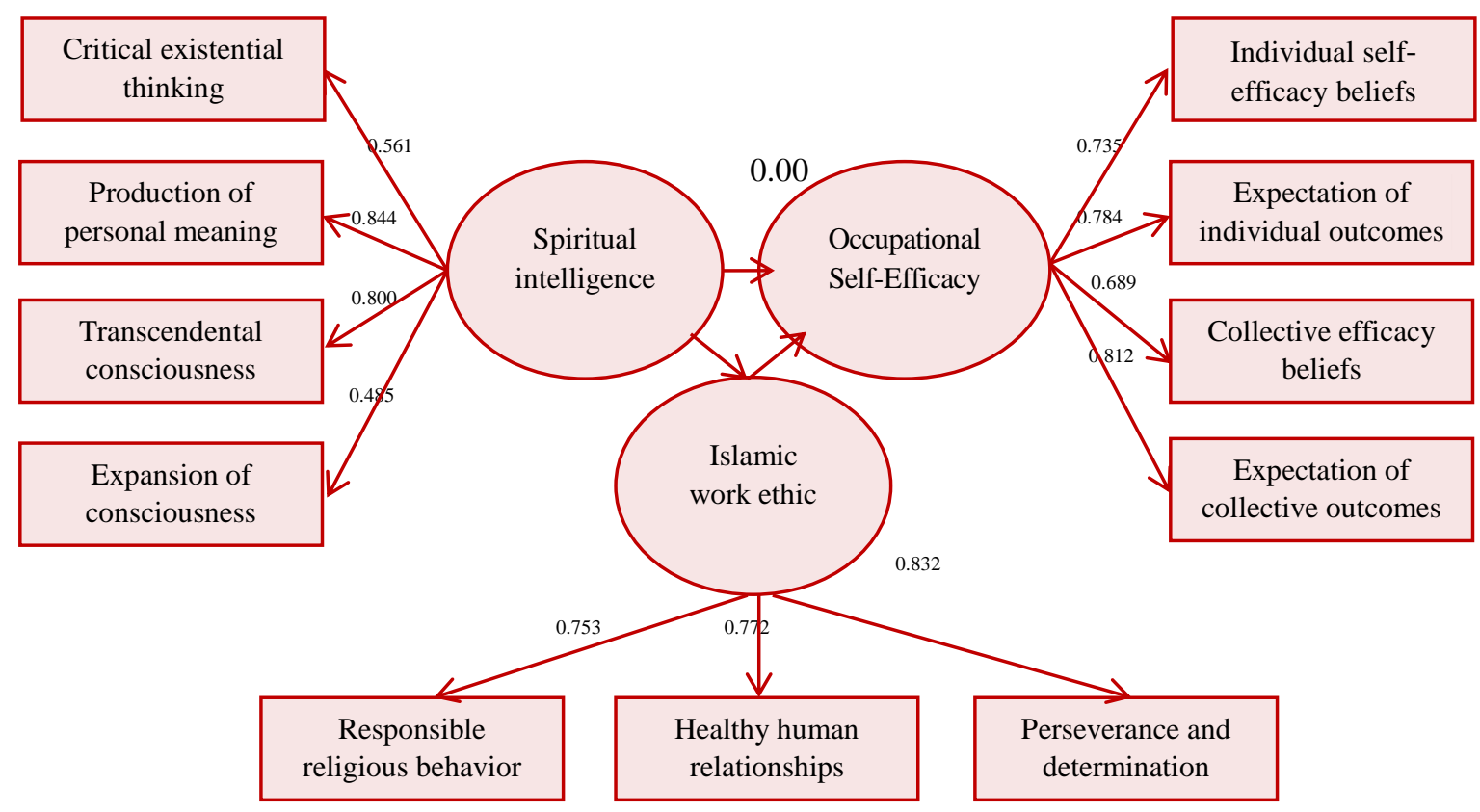

Figure 1. Main research model in the mode of coefficient estimation 


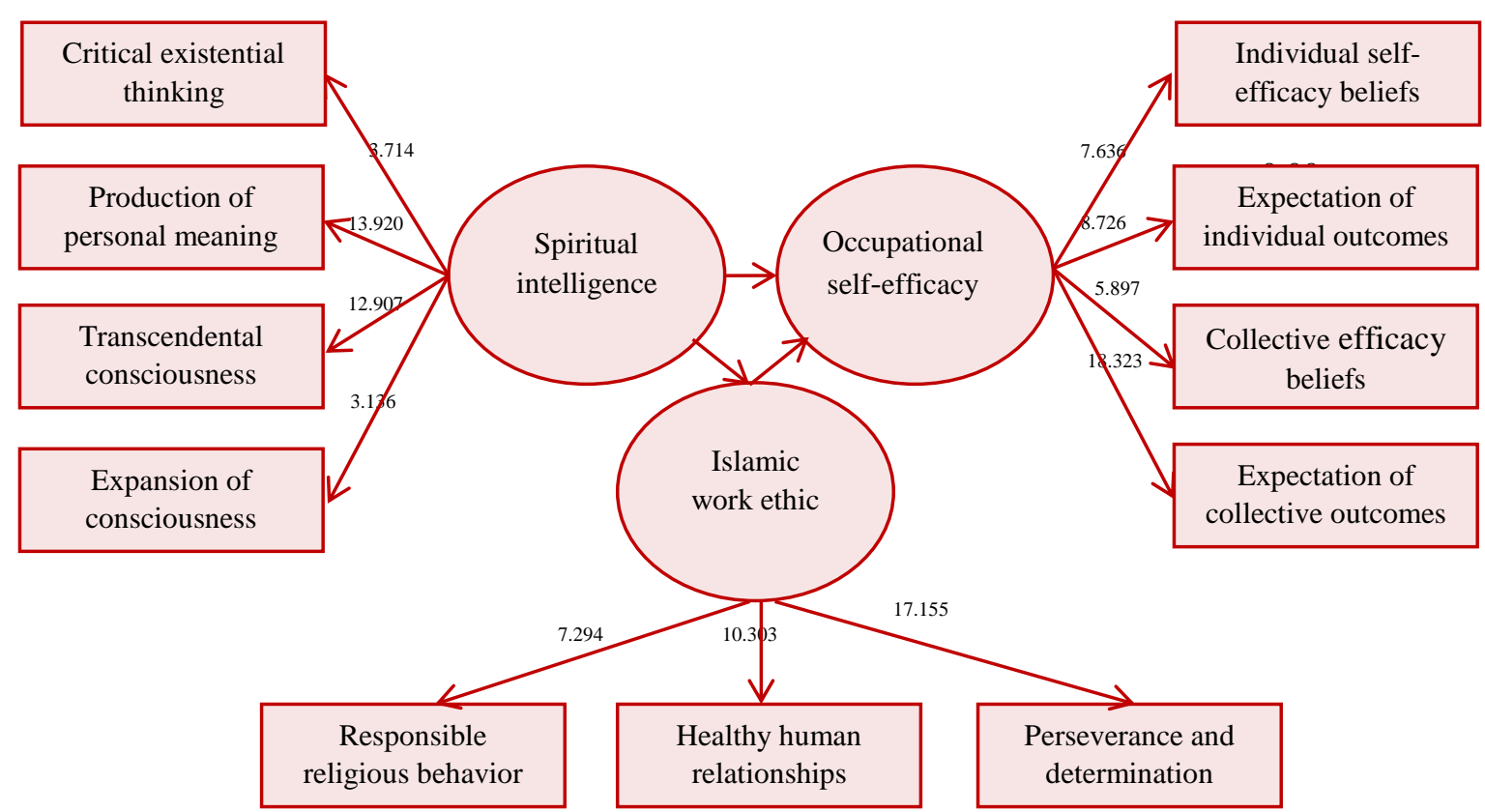

Figure 2. Main research model in the mode of coefficient significance

for confirmation or rejection of the hypotheses. If it exceeds 1.96, there is a relationship between the two variables, and the hypothesis is confirmed at the confidence level of $95 \%$.

Since the t-value for the effect of spiritual intelligence on occupational self-efficacy is 2.330 , which is more than 1.96 , it can be said with confidence that the hypothesis is confirmed and spiritual intelligence affects occupational selfefficacy. Other hypotheses have also been examined and their results are summarized in tables 3 and 4 which indicate that two of the hypotheses have been rejected and the other hypotheses of the research have been confirmed.

\section{Discussion and Conclusion}

This study mainly aimed to investigate the mediating role of Islamic work ethic in the relationship between spiritual intelligence and occupational self-efficacy of Red Crescent relief workers in Torbat Heydariyeh. In the following, the outcomes of hypotheses testing are presented and compared with the results of the previous research.

According to the results of the structural equation modeling test with the PLS method and based on the path coefficient and t-statistic, it can be concluded that there is a significant relationship between spiritual intelligence and self-efficacy in Red Crescent relief workers. This is in line with the findings of the studies performed by Karimi
Monjermoei (2015), Moghari (2014), Mansour Ali et al. (2012), Golchin (2012), Adebula (2007), and Wigglesworth (2006).

The results also revealed that two components of spiritual intelligence, namely critical existential thinking and production of personal meaning have a significant relationship with the self-efficacy of Red Crescent relief workers. This is consistent with the findings of the studies carried out by Karimi (2014), Mansourali et al. (2012), and Golchin (2012). Based on the results, Islamic work ethic and its components mediate the relationship between spiritual intelligence and self-efficacy which is in line with the results of the research performed by Karimi (2014), Mogheri (2014), Rajabipour Meybodi (2013), Santoso (2016), and Rokhman (2010).

Results of the hypothesis testing are the basis of the potential recommendations. The researcher has tried to provide practical suggestions based on the obtained results and provide solutions for the existing problems in the way of the target organization of this research. Red Crescent community leaders are advised to persuade relief workers by training to create a strong sense of change in themselves. This ability can help them discover problems and solve them and also encourages them to give a new meaning to their relationship with the environment, others, and God.

Relevant managers and officials are 
encouraged to allow relief workers to express their critical feedback, suggestions, and thoughts. It is recommended for the managers to hold training classes and various workshops to create the ability and power of thinking as well as internal and external cognition in the relief workers. Managers are suggested to build a culture based on Islamic ethical rules and be role models for their employees in order to promote Islamic work ethic.

It is suggested that in the workplace, discrimination and inappropriate relationships be avoided, justice and equality be sought in accordance with the teachings of Islam, and selfefficacy be developed by awakening moral and human conscience. Furthermore, managers and relief workers are advised to always consider hard work, commitment, and dedication in their work and avoid unethical methods of cooperation and competition in the workplace.

Due to the significant role of responsible religious behaviors in the relationship between spiritual intelligence and occupational selfefficacy, managers are suggested to familiarize relief workers with the teachings of Islamic work ethic and develop a sense of independence, selfesteem, and responsibility in them. In general, the development and reinforcement of spiritual intelligence as well as the promotion and institutionalization of Islamic work ethic can lead to the professional efficiency of relief workers and their more effective performance.

\section{Acknowledgments}

The authors would like to express their gratitude to all those who contributed to the conduction of this research project.

\section{Conflict of Interests}

Authors have no conflict of interests.

\section{References}

1. Akbari Z, Pakdaman M, Momeni Mahmouei H. A study of the relationship between self-efficacy and job satisfaction with academic achievement in experimental, mathematical and Persian courses for fifth grade elementary students. $3^{\text {rd }}$ International Conference on Behavioral Science, Kish Island, Iran; 2013. [In Persian].

2. Keshavarz L, Barazadeh H, Molajafari A. Determining the predictor factors of carrier selfefficacy among Tehran sport board's managers.
Sports Manag Stud 2015; 6(27): 199-218. [In Persian].

3. Karimi H. The relationship between spiritual intelligence, automation, and job stress among education staff in Kavar. [Master Thesis]. Marvdasht: Islamic Azad University, Marvdasht Branch; 2014. [In Persian].

4. Shir Mohammadzadeh M, Ghasemzadeh Alishahi A, Kazemzadeh Beytali M. The mediator role of occupational self-efficacy in the relationship between professional development and job commitment and satisfaction among sports and the youth department's staff. Iran J Ergon 2018; 6(1): 30-9. [In Persian].

5. King DB. Rethinking claims of spiritual intelligence: a definition, model and measure. [Master Thesis]. Canada: Trent University; 2008.

6. Mogheri H. A study of the relationship between spiritual intelligence and self-efficacy of Tehran gas company employees. [Master Thesis]. Shahroud: Islamic Azad University, Shahroud Branch; 2014. [In Persian].

7. Karimi H, Zarei R, Valizadeh N. Effects of emotional intelligence, spiritual intelligence, and mental health to reduce academic burnout and to boost academic performance of agricultural students. Agr Educ Admin Res 2018; 10(47): 155 39. [In Persian].

8. Rastegar Shahbandi S. Prediction of responsibility based on spiritual intelligence, considering the intermediary role of resiliency. Soc Educ 2018; 9(9): 79-94. [In Persian].

9. mram JY. The contribution of emotional and spiritual intelligences to effective business leadership. California: Institute of Transpersonal Psychology; 2009.

10. Khani JJ. Moral and job conscience in entrepreneurship. Ethics Sci Technol 2008; 3(3-4): 91-6. [In Persian].

11. Meybodi AR, Dehghani M. The relationship between Islamic work ethic and organizational commitment and job satisfaction of nurses. Bioethics J 2013; 2(6): 49-92. [In Persian].

12. Soltanzadeh M. The study of work culture and work ethic in Iranian society from a sociological perspective. [Master Thesis]. Kerman: Shahid Bahonar University of Kerman; 2005. [In Persian].

13. Ali AJ, Al-Owaihan A. Islamic work ethic: a critical review. Cross Cultural Manag Int J 2008; 15(1): 5-19.

14. Saadat Khatouni $\mathrm{S}$. The effect of Islamic work ethic on the factors of organizational commitment, job satisfaction and job dependence. [Master Thesis]. Tehran: Islamic Azad University, Central Tehran Branch; 2013. [In Persian].

15. Yousef DA. Organizational commitment and job satisfaction as predictors of attitudes toward 
organizational change in a non-western setting. Pers Rev 2000; 29(5): 567-92.

16. Alemi $M$. The relationship between religion and ethics (study of perspectives on the relationship between religion and ethics). Qom: Boostaneketab; 2010. [In Persian].

17. Golparvar M, Nadi MA. Mediating role of organizational loyalty in relation between work ethic with deviant workplace behavior. Ethics Sci Technol 2011; 6(1): 43-52. [In Persian].

18. Keiwanloo Shahrestanaki L. A study of the causal relationship between Islamic work ethics and job satisfaction and organizational commitment mediated by internal employee motivation. [Master Thesis]. Bojnord: University of Bojnord; 2015. [In Persian].

19. Okhman W, Omar A. The effect of Islamic work ethics on job satisfaction, organizational commitment and turnover intention: a study on Islamic microfinance institutions in Central Java, Indonesia. J Busin Manag 2008; 4(1): 20-8.

20. Kumar N, Rose RC. Examining the link between Islamic work ethic and innovation capability. J Manag Dev 2010; 29(1): 79-93.

21. Saadat Khatouni S. The effect of Islamic work ethic on the factors of organizational commitment, job satisfaction and job dependence. [Master Thesis]. Tehran: Islamic Azad University, Central Tehran Branch. 2013. [In Persian].

22. Karimi J. Explaining the role of Islamic work ethic on the self-efficacy of basic science professors at Payame Noor University in Shahrekord. [Master Thesis]. Tehran: Payame Noor University of Tehran Province; 2016. [In Persian].

23. Dayyeri Z, Barzegar M, Sarvghad S. The relationship between coping strategies with stress, self-efficacy and psychological hardiness in relief workers of Red Crescent society of Kohgiluyeh and
Boyer-Ahmad province. J Rescue Relief 2015; 6(4): 66-76. [In Persian].

24. Mansourali M, Fahimi S, Shahsavari Z. The relationship between spiritual intelligence and general self-efficacy in students. $2^{\text {nd }}$ National Conference on Psychology of Counseling and Religion, Isfahan, Iran; 2012. [In Persian].

25. Golchin A. The relationship between spiritual intelligence and self-efficacy of high school teachers. [Master Thesis]. Tehran: Payame Noor University; 2012. [In Persian].

26. Antoso B. The role of Islamic work ethic, spiritual leadership, and organizational culture toward attitude on change with organizational commitment and job involvement as mediator on bank Pembiayaan Rakyat Syari'ah (BPRS) Indonesia. Int Rev Manag Busin Res 2016; 5(3): 827.

27. Mith JP. The effects of self-efficacy and spirituality on the job satisfaction and motivation to lead among redeploying soldiers as moderated by transformational leadership. [PhD Thesis]. Virginia: Regent University; 2010.

28. Ali AJ, Al-Kazemi AA. Islamic work ethic in Kuwait. Cross Cultural Manag Int J 2007; 14(2): 93-104.

29. Rokhman W. The effect of Islamic work ethics on work outcomes. Electron J Busin Ethics Organ Stud 2010; 15(1): 21-7.

30. Adegbola MA. The relationship among spirituality, self-efficacy and quality of life in adults with sike cell disease. [PhD Thesis]. Arlington: University of Texas; 2007.

31. Wigglesworth C. Why spiritual intelligence is essential to mature leadership. Integral Leadership Rev 2006; 6(3): 2006-8.

32. McKnight D. An investigation into the relationship between spirituality and life satisfaction. California: California State University; 2005. 